\title{
Unfinished business in the international dialogue on debt
}

\section{Barry Herman}

Chief, Policy Analysis and Development, Financing for Development Office,

Department of Economic and Social Affairs,

United Nations

herman@un.org
From November 2001 to April 2003, the International Monetary Fund grappled with a radical proposal, the Sovereign Debt Restructuring Mechanism, for handling the external debt of insolvent governments of developing and transition economies. That proposal was rejected, but new "collective action clauses" that address some of the difficulties in restructuring bond debt are being introduced. In addition, IMF is developing a pragmatic and eclectic approach to assessing debt sustainability that can be useful to governments and creditors. However, many of the problems in restructuring sovereign debt remain and this paper suggests both specific reforms and modalities for considering them. 


\section{I}

\section{Introduction}

A new sense of calm descended on the international markets for emerging-economy debt in mid-2003. The calm was seen in rising international market prices of sovereign bonds of emerging economies in the first half of the year and good sales of new bond issues, in particular those of Brazil and Mexico, as well as the successful completion of Uruguay's bond exchange offer. Market nervousness before then had been set off by two developments in 2001: the Argentine Government's slide into the largest default ever and the fear of contagion in other countries, and the proposal in November by Anne Krueger, the First Deputy Managing Director of the International Monetary Fund (IMF), to create a new international insolvency regime for governments that could no longer service their foreign debt.

The IMF proposal, coupled with the Argentine crisis, was read by the financial markets as a message that the IMF and the major industrialized countries were setting definite limits on their willingness to extend international liquidity to emerging economies in balance-of-payments crisis. Large amounts of funds could still be mobilized in support of policy reforms for countries deemed to be cooperating in resolving their difficulties, especially where there was a major global security interest, as had been the case in Turkey during the same period. Even in security-sensitive situations, however, default had to be considered a realistic possibility, as the Russian crisis had shown in 1998. The IMF proposal thus said, in essence, that if defaults were going to happen, then a better mechanism was needed to restructure the debt, especially as there would be limits to the financial efforts to prevent them.

In fact, modest changes have been made in how future sovereign insolvencies will be treated, and the

Views expressed herein are those of the author and not necessarily of the United Nations. This paper carries forward a discussion originally prepared for the Intergovernmental Group of Twenty-four on International Monetary Affairs Technical Meeting in Port of Spain, Trinidad and Tobago, on 13 and 14 February 2003 (see Herman, 2003). Comments of participants in that meeting have helped shape this paper and are gratefully acknowledged, as are those of an anonymous referee of an earlier draft paper. international financial markets and government issuers alike have accepted them. They address certain concerns about how the external bond debt of crisis countries is restructured, although some market participants discount the likelihood that those concerns were any more than theoretical difficulties. This paper will argue that the changes that were adopted leave unresolved the basic concerns that made the IMF proposal so important, namely its implicit recognition that an adequate, timely and fair restructuring of external debt should be an assured part of the international policy to assist insolvent countries. The hard part is figuring out how to do that.

The international financial markets have for the time being discounted the concern that something is missing in the international mechanisms for treating problem debt, as they are looking with increasing favour on emerging economies in 2003. ${ }^{1}$ While the Argentine debt situation was still unresolved as of the time of writing in August 2003, Argentina's economy had begun to recover behind more effective macroeconomic policies. Perhaps most significantly, the market no longer feared that other large sovereign debtors would newly seek to restructure their debt at this time. In other words, the change in government in Brazil had been smooth and the IMF proposal for radical reform of the debt relief process did not gain the broad support necessary for its enactment.

Indeed, the IMF proposal had generated significant opposition among developing-country governments, especially in Latin America, and in financial markets that lend heavily to this region. The United States Government gave the coup de grâce to the proposal at the April 2003 meeting of the Fund's International Monetary and Financial Committee when it declined to support further work on it. Nevertheless, economic policy in response to default has not changed at all and the existing debt workout mechanisms remain a haphazard collection of not necessarily coherent

\footnotetext{
${ }^{1}$ This notwithstanding, market professionals have not been expecting developing countries to see more than a modest net increase in flows in 2003 (Institute of International Finance, 2003).
} 
processes. If the IMF proposal was not an adequate way to achieve the desired outcome, neither are the modest changes that were adopted.

The discussion that follows seeks to outline the essential characteristics of default on external sovereign debt (section II) and why debt restructuring is inescapably difficult (section III). Section IV then discusses the IMF proposal and its shortcomings. Section $\mathrm{V}$ describes changes that have been introduced in 2003 in relation to sovereign bond restructuring and how these have left open many important questions. Section VI concludes by suggesting how to work towards a more adequate, timely and fair process for restructuring the external debt of countries in crisis.

\section{II}

\section{Insolvency and the nature of the policy intervention}

Any debt crisis represents a failure. All borrowers solemnly pledge to repay their loans with interest according to a fixed schedule in a contract. Default violates the contract. Pledged collateral may cover more or less of the debtor's obligations to the creditor, but unsecured loans, as to governments, leave the creditors fully exposed to loss. What can or should the creditors do to recover their funds? What rules should they operate under and who should make those rules?

In the eighteenth century in Europe and the United States, defaulters went to prison. This usually did not help the creditors recover their loans, although it was believed to discourage default. Prison under harsh conditions was the ultimate policy to deal with the "moral hazard" that people might take on excessive debt without adequate consideration of their obligation to repay. However, with the spread of "limited liability" corporations as a means of undertaking business activity, creditors of defaulting corporations could collect only the remaining assets of the insolvent company to cover their unsecured loans. Creditors could not touch the personal wealth of the owners or managers, let alone send them to prison, although insolvent companies ceased to exist. This effectively limited creditor rights of recovery and in doing so fostered the larger accumulation of funds needed by the business entities that became the backbone of the industrialization of the now-developed world.

Corporate insolvency meant the assured death of the company, which was possibly too drastic, until a new idea took hold. This idea was that sometimes restructuring the firm under court supervision but with the "debtor in possession" could salvage it and thus protect more of the claims of the creditors, not to mention the jobs of its employees, than closing down the firm, breaking it up and selling its assets. This approach began in the United States in the nineteenth century as an emergent practice to handle defaults of railroad companies, although it was later codified in the famous Chapter XI of the United States Bankruptcy Code. ${ }^{2}$ Defaults by government borrowers have an even longer history than corporate defaults and have necessarily always been matters of restructuring. ${ }^{3}$ Today, personal bankruptcies are also matters of debt restructuring, as there are no more debtors' prisons.

In each case in which debt restructuring is applied, whether personal, corporate or sovereign, the object of the restructuring is to help the bankrupt entity make a new start, sacrificing as many of the claims of the creditors as warranted but not more than is deemed necessary. Where to draw the line is, of course, the difficult part. The debtor should be expected to survive after the restructuring and not need subsequent relief under normal circumstances and sound management. Concepts of social justice place limits on how close to survival minimums the creditors should be allowed to put the debtor; e.g., indentured servitude (in effect, temporary slavery) is no longer allowed in personal bankruptcy. But should the debtor "prosper" on the back of creditor losses? In the case of sovereign bankruptcy,

\footnotetext{
${ }^{2}$ See Bolton (2002).

${ }^{3}$ It has even been argued that relations between sovereigns and their creditors have been an important factor in shaping the development of "Western civilization"; e.g., they are said to have been an important determinant in the growth of democracy (Schultz and Weingast, 2003; Macdonald, 2003).
} 
the answer is yes. Poor countries, in particular, should have the opportunity to become rich countries even if they default at some point on their loan repayments and need to restructure their debt. At least, this is presumed to be a general principle.

In cases of personal and corporate insolvency, the domestic court system oversees the debt workout, as loans are legal contracts subject to court enforcement. This also gives some comfort to the debtor these days, as the courts operate under the legal and political apparatus of the State and are expected to apply constitutional principles and societal norms in their decisions. The first problem in the case of sovereign default on external loans is that there is no global court to oversee the process and ensure it is "fair" as might be defined in some form of international law.

The second problem in sovereign default also stems from the absence of any global bankruptcy court. Most debtors have obligations to multiple creditors. Any one creditor may not even know about the existence of the others, or the amounts owed to each or to all of them together. A bankruptcy court facilitates bringing all the creditors together and organizing their negotiations according to the principles and processes stipulated in the legislated guidelines of the relevant bankruptcy law.

In the case of defaulting sovereigns, there are only political understandings to govern the amount and allocation of debt relief, and $a d h o c$ and informal practices to organize the actual negotiations. Debts owed to major government creditors are restructured in the Paris Club, largely represented by the interests of their export credit agencies. Paris Club members determine among themselves what terms to offer (on advice from IMF) and then press the debtor to obtain comparable terms from non-Paris Club official creditors and from private lenders (multilateral institutions being exempt from debt restructuring in most cases). Debts owed to commercial banks are usually renegotiated with an advisory committee (London Club), which reaches a tentative agreement with the government that it puts to the bank creditors for decision. Debts in the form of international bonds have been the hardest to restructure and have been the focus of the recent policy reforms, which aim to make reaching agreement easier than in the past (see below).

Each member of each of the main creditor groups and other creditors as well (e.g., unpaid suppliers to the government) are motivated to maximize their individual loan recovery, even at the expense of the other creditors. Nevertheless, the clubs of government and bank creditors and the bondholder arrangements under the new reforms can impose a measure of discipline on members of their groups through contract or informal pressures. There is no formal mechanism to ensure that sacrifice is comparable or appropriate across the groupings of creditors or that overall relief is sufficient for realizing the presumed general goal, that the remaining debt not prevent the economy from being able to develop.

IMF usually plays an informal role in coordinating the creditors and assessing the adequacy of relief, as part of its broader engagement with debt-crisis countries. But while a bankruptcy judge at domestic level would follow legal guidelines and precedents, the staff of IMF follows political guidelines given by the International Monetary and Financial Committee at ministerial level and the IMF Executive Board at operational level. Moreover, each debtor country's overall programme has to be approved by the Executive Board, which also monitors its implementation. In other words, instead of a legal/judicial approach, IMF follows a political one, wherein the relative influence of different countries on the Board reflects the size of their shareholding in the Fund.

IMF also differs importantly from a court in that it is not a neutral party to the matter being decided. IMF is itself a creditor, moreover a "preferred" creditor that must be paid before non-preferred creditors. In the preferred creditor institutions (mainly IMF, the World Bank and the regional development banks), the main shareholders are said to be willing for their institution to lend to countries in crisis when other creditors will not because they are assured they will be first in line to be repaid. Thus, when IMF negotiates an adjustment programme with a defaulting government, all creditors understand that IMF will seek to ensure that there is sufficient hard currency cash flow to service the outstanding loans of itself and the other preferred creditors. The quid pro quo is that these multilateral creditors in fact extend new loans and the defaulted creditors will press to have those loans be as large as possible, indeed large enough to constitute a "bail-out" and erase prospective private creditor losses.

The required amount of debt relief (certainly its phasing over time) thus depends in part on the size of new lending by IMF and other multilateral creditors, besides any bilateral loans and grants that might be accorded by different departments of the same governments that are negotiating debt relief in the Paris Club. It also depends on other prospective financial flows into and out of the country, the exchange rate, and targets for the balance of trade in goods and services and the government's fiscal position, and 
simultaneously for the growth of output and income in the crisis country. One may imagine an iterative process involving IMF as coordinator, the debtor country government, its official multilateral and bilateral creditors (including IMF as lender), and the various sets of defaulted private and official creditors, wherein alternative packages of domestic macroeconomic policies, new financial commitments and debt relief are considered, albeit not simultaneously, until a consistent package is accepted at least by all the major players. That package reflects the bargaining strength of each group and is not necessarily optimal from the perspective of any one of them, let alone of the people in the crisis country who bear the brunt of the economic adjustment that accompanies the debt workout.
Indeed, the local people are probably the group least consulted in developing the package, a complaint that has led large coalitions of non-governmental organizations working in heavily indebted countries to call for the current approach to be replaced by a "fair and transparent arbitration process". 4 Yes, but arbitration is a form of legal process for dispute resolution, like a bankruptcy court, and this leaves open the question of what guidelines the arbitrators should follow and who should set, review and revise them over time. While the legislature is the answer to such questions at national level, treaties among governments are the general answer at the global level, as well as specifications in loan contracts themselves.

\section{III}

\section{The arcane analytics of debt sustainability}

Instead of determining the debt relief package by negotiation, might it be determined by dispassionate analysis? The answer is no. Whether or not there is any such thing as an "optimal" debt relief package, there is no way to determine what that package is. The experience of IMF and the World Bank in trying over the years to determine how much debt relief is required for the heavily indebted poor countries (HIPCs) illustrates the problem: even in these financially simpler cases in which almost all of the debt is owed to official agencies, much of the analysis and thus the decisions have to be judgemental. Decisions in such an environment are inevitably reached through negotiation. Debtors press for as much relief as possible and creditors - even official ones who might have been thought able to make the political decision to approach the situation from a broad development perspective, given the relatively small sums at stake- seek to give away as little as possible.

Before the HIPC Initiative was launched to lower such countries' debts, creditor governments only gradually and reluctantly agreed on the need to accord increasingly large reductions in the stock of debt owed them by HIPCs, while no rescheduling, let alone reduction, of multilateral loans was even contemplated. In 1996, the World Bank and IMF launched the HIPC
Initiative, which required that creditor governments finally address the essential question of how much the debt had to be cut to leave the HIPCs with a "sustainable" debt level, understanding that for possibly about 40 countries this could mean extremely deep cuts in obligations to creditor governments and reduced obligations to the multilateral institutions, as well as to all other creditors. ${ }^{5}$

\footnotetext{
${ }^{4}$ For a detailed presentation, see Fritz and Hersel (2002). Major advocates for this approach include Jubilee Research (New Economics Foundation), Jubilee Germany (erlassjahr.de), International Cooperation for Development and Solidarity (CIDSE), Caritas Internationalis, and other organizations (important initial and continuing work on the idea has been done by Kunibert Raffer at the University of Vienna).

${ }^{5}$ The debt relief objective of the HIPC Initiative evolved from "reducing debt as part of a broader strategy to achieve long-run sustainability" in preliminary analytical work in 1995, to "reducing debt to sustainable levels and thus providing a durable exit strategy from the rescheduling process" in the original World Bank/IMF formulation of the Initiative in 1996, to "providing a robust exit from debt rescheduling and the achievement of debt sustainability" in 1998 in a Bank/Fund paper, to a "permanent exit from the rescheduling process and a clear exit from unsustainable debt" in the 1999 enhancement of the HIPC Initiative (World Bank, 2003, p. 12 , italics in original).
} 
For political reasons, the guidelines for how much relief to give each country needed to be relatively simple and comparable across countries. The HIPC Initiative thus established rules of thumb for what key debt and macroeconomic indicators should be after completion of all HIPC relief. The primary indicator was that the debt of each HIPC should be brought down to between $200 \%$ and $250 \%$ of its exports after debt reduction. The HIPC Initiative had planned for up to six years of country policy reform and monitoring, with calculation at an intermediate benchmark called the "decision point" of the relief that would be given at the "completion point". In its initial form, the IMF and World Bank were to forecast from the decision point what the debt/export ratio would be at the completion point and thus how much debt relief was needed to meet the target. In the 1999 HIPC enhancement, both the target ratio and the means of calculating it were changed. The target ratio was reduced to $150 \%$ on the grounds that the HIPCs needed an "appropriate cushion". Explanations aside, this was an admission that the higher ratio underestimated the necessary amount of relief. In addition, instead of a forecast, data at the time of the decision point were to be used to estimate the relief needed to meet the target. This would presumably help control for over-optimistic forecasts. Moreover, the amount of relief at the completion point could be "topped up" if it were decided that the country's debt situation had changed "fundamentally" from the decision to completion points (i.e., if its post-relief debt/ export ratio would otherwise remain significantly above the target).

Additional specifications had to be made before the seemingly simple debt/export indicator could actually be measured. Firstly, as was proposed in the HIPC enhancement, the denominator of the debt/export ratio should be the value of exports in the decisionpoint year. Uganda was the first country to qualify for HIPC relief and it complained that as its export prices had been at a cyclical peak, it would receive insufficient relief under such a calculation. Instead, Uganda argued for an average of the past six years' exports. That was considered too pessimistic (too favourable to Uganda) and a three-year average was approved, which became the standard for the 1999 enhancement (World Bank, 2003, box. 4.1).

It was also decided that the numerator in the ratio should not be the nominal amount of debt, but the present value of the future debt-servicing stream. This is an appropriate calculation to make, as much of the debt of the HIPCs is concessional and the nominal debt level would overstate the effective debt to be serviced. However, the net present value (NPV) of debt-servicing obligations depends on how it is calculated. The higher the discount rate is, the smaller will be the present value of any given stream of obligations over time. The discount rate should reflect the opportunity cost of hard currency funds for the government, assuming for convenience that the funds would be held in official foreign exchange reserves if not utilized for debt servicing. But what should that interest rate be? The "proper" rate is an unknown future interest rate over the debt-servicing horizon. The current practice is to take six-month historical averages of the yields on fiveyear government bonds for each currency of the debt (IMF, 2003b, pp. 19-21). However, the discount rate calculated this way in 2000 would have been significantly higher than that calculated in 2003, meaning more relief would be deemed necessary in 2003 than three years before to reach the same NPV/ export ratio. Indeed, international interest rates are expected to rise again in ensuing years, which means the calculated NPV on an unchanged stream of debt servicing would correspondingly shrink.

One may thus see that there was room for dispute and negotiation by the creditor and debtor governments and staff of the Bretton Woods institutions on each element in the calculation of what is in the end a relatively arbitrary rule of thumb (e.g., it takes no account of the import side of the balance of payments). Moreover, IMF has recently proposed a general definition of "debt sustainability" that is itself a good argument against any rule of thumb, namely, "a situation in which a borrower is expected to be able to continue servicing its debts without an unrealistically large future correction to the balance of income and expenditure" (IMF, 2002a, p. 4). This is an attractive definition because it draws attention to the possible impact of "debt correction" on the people in a debt-crisis country. In essence, it takes account of the fact that sovereign defaults are political decisions about which government expenditure obligations to meet and which not to meet, rather than an absolute absence of funds. Indeed, governments could decide to squeeze their populations a great deal in order to avoid actual default, and that situation would be deemed "unsustainable" under the Fund's definition.

While conceptually attractive, this definition of sustainability is not simple to make operational. Indeed IMF has adopted a complex framework for monitoring debt sustainability (IMF, 2002a and 2002b). The essential element, it implicitly argues, is not whether a 
country gets to the "proper" debt/export ratio after its debt is restructured, but whether the country has a reasonable chance to keep whatever debt level it starts with from rising back to unsupportable levels. This depends, inter alia, on export growth (and for lowincome countries, often an ability to diversify exports), terms-of-trade trends, broadening the tax base and efficiently managing public expenditure (recalling this is about sovereign debt), as well as trends in foreign direct investment, capital flight, whether there is a natural catastrophe or sustained civil unrest and, for low-income countries, how much of their financial assistance is provided in grant form, etc.

IMF has routinely undertaken exercises to assess debt sustainability in the context of its macroeconomic projections, but independent analysts such as the United States Government Accounting Office and the World Bank's own Operations Evaluation Department (OED) have found the ones prepared on the HIPC countries in particular to be unclear and insufficiently documented. OED has thus called for "a more transparent, explicit, and consistent methodology for the debt projections that connects all the relevant components of the fiscal budget, national accounts, financial flows and the balance of payments" (World Bank, 2003, p. 24).

World Bank management accepted this recommendation, as did IMF implicitly when it began to bring together different aspects of its monitoring of member country performance and outlook into a more coherent framework of variables to track and forecast so that external and public-sector debt sustainability could be assessed over the medium term. It also decided to carry out standard sensitivity analyses on the forecasts (such as evolution under historical norms instead of the baseline forecast), along with "stress tests" (more extreme scenarios). It sees the purpose of this framework, which will evolve in the light of experience in use, as being "to make better informed judgements possible and to discipline those judgements by laying bare the basis on which they are made, rather than to distil a single measure of sustainability that would eliminate the need for judgement" (IMF, 2002a, p. 24). As though to underline the point, the word "judgement" appears 22 times in the 40 pages of text in the IMF framework paper. Moreover, the Fund eschews any estimate of the probability that any of its scenarios will happen (perforce including the baseline), leaving that judgement also to the "user" (IMF, 2002a, p. 25).

The remaining question is who are the users? The IMF staff put this question to its Executive Board in reviewing the framework. As the Managing Director summarized the discussion: "Clearly there is a tension, in this regard, between the view that publication would enhance the credibility of the Fund's sustainability assessments and strengthen its accountability (the staff view), and the concern that, given the sensitivity of the subject, publication could lead to misinterpretations by the public and adverse market impacts" (IMF, 2002a, p. 3).

As the IMF framework itself is already public, and as private creditors use similar methodologies in assessing the outlook in emerging economies, it seems that governments should welcome Fund publication of its assessment and a general debate about it. That debate should inform decisions by legislatures on budgets, analyses by journalists and academics who follow developments in the economy, civil society advocates and of course potential and actual creditors and investors. ${ }^{6}$ Moreover, as sovereign debt restructuring is actually a political process, as argued here, it should allow for the broadest feasible debate on its terms by all the relevant stakeholders.

\footnotetext{
${ }^{6}$ A case for a continuous mechanism for conversation between a government and its creditors, which could draw upon the Fund's debt sustainability framework, is made in Herman (2003).
} 


\section{IV}

\section{The Sovereign Debt Restructuring Mechanism fails to solve the problem}

The argument thus far is that debt crisis workouts are inescapably matters for negotiation among the relevant stakeholders rather than analytical solution, and that the court-supervised processes and guidelines that facilitate debt negotiations in a domestic context have only an informal, partial and political counterpart for the case of sovereign debt. When IMF proposed creating a Sovereign Debt Restructuring Mechanism (SDRM) in late 2001, it at first appeared that it was proposing a global bankruptcy court for governments. In fact, much less was being proposed, although it was far more than was politically acceptable.

The SDRM might have brought all the creditors of a government in external debt crisis together for a comprehensive set of debt negotiations. IMF did propose bringing all the classes of private creditors (commercial banks, bondholders, suppliers) into the SDRM and left open the question of whether bilateral government creditors would be incorporated as another class or would conduct a parallel negotiation. ${ }^{7}$ As the Paris Club expressed the view that there was no need (desire) to change its operations, it was effectively dropped from the SDRM. ${ }^{8}$

Even restricted to private creditors, the IMF proposal would have been a major innovation. It proposed, in particular, creating a new international legal mechanism, the Sovereign Debt Dispute Resolution Forum (SDDRF), which would have had some of the responsibilities of an international

\footnotetext{
7 The SDRM was not intended to be used for HIPCs and so it was assumed that multilateral creditors would not be part of the debt negotiations per se.

${ }^{8}$ In its final report to the International Monetary and Financial Committee, the Fund staff left the exclusion of bilateral official claims in "square brackets", meaning not yet agreed and requiring further discussion (IMF, 2003a, paragraph 3d). Later in the year, the finance ministers of the Group of Seven (2003) decided that the Paris Club should modify its approach to restructuring, adopting an approach more comparable to that taken by private creditors when they agree to reduce the debt stock (as through bond swaps), in contrast to repeated traditional Paris Club rescheduling of debt servicing obligations.
}

bankruptcy court. After being called upon by a defaulting government, it would have overseen the formation of different classes of the country's creditors into negotiating groups, validated the claims of individual creditors, and resolved disputes on the placement of individual creditors into the different classes. It would also have been able to prevent individual creditors from disrupting the SDRM process, although there was no agreement on whether SDDRF needed the ability to block legal actions in domestic courts against the debtor government (i.e., enforce a "stay on litigation") or whether a more limited set of powers would suffice. ${ }^{9}$ Finally, it would have overseen creditor voting within each class, as on such matters as who should represent them in their negotiations or on the final agreement.

Each of the chosen group negotiators would then have been charged with developing with the government a precise restructuring proposal for their class of creditors. In addition, a steering committee of the various classes of creditors might have been formed to coordinate their various negotiations and check on the coherence of the overall financial package that emerged (one reason it would have been desirable to have the Paris Club inside the SDRM process). The government would then have formally proposed the component draft agreements to each class, which would have voted on them, all of this overseen by the SDDRF. The overall debt agreement would have been considered adopted when approved by $75 \%$ of the outstanding principal of registered claims in each class (IMF, 2002c, especially paragraphs $157-168$ and 183-208).

While the negotiations would probably have begun with a draft IMF adjustment programme and a target overall level of debt relief, the steering committee would

\footnotetext{
${ }^{9}$ One alternative was the "hotchpot rule", which in essence would subtract from a successfully litigating creditor's share of a final group settlement whatever was won through its litigation, neutralizing its gain. Another proposal was to give SDDRF the power to enjoin enforcement of individual creditor court actions that would otherwise undermine the collective restructuring agreement (IMF, 2002c, paragraphs 124-141).
} 
presumably have been able to raise questions in its own meetings about the overall adequacy of the programme and the envelope of presumed new multilateral and bilateral official financing. ${ }^{10}$ The steering committee could conceivably even have reached the conclusion that the overall financial and policy package would not lead the country to a sustainable debt situation (owing to pessimistic export forecasts, say), in which case their post-agreement credits would have been of uncertain value, not to mention defeating the purpose of the debt restructuring exercise itself. In that case, the committee might have sought a way to urge the debtor government to reopen its discussions with IMF, and right here it may be seen that the closeness of IMF to the SDRM was a problem: where would that discussion have taken place? It does not appear that such concerns could have been addressed to the SDDRF, which was not intended to have a substantive role. Perhaps the only avenue open to the creditors would have been to reject the debt restructuring package by voting it down, ending the SDRM oversight. In other words, formalizing the debt renegotiation mechanism without a coherence mechanism would have omitted a necessary counterpart to the informal or even implicit iterations between government, creditors and IMF in the existing process.

In effect, IMF would have been "just behind the curtains" during the debtor government's negotiations with the different classes of creditors, as it is today. ${ }^{11}$ There was, however, an effort to create a space between IMF and the more legal side of SDRM. That is, the Fund proposed a complicated mechanism for selecting the SDDRF judges, by which relevant international organizations and professional associations would have advised the Managing Director of IMF on prospective candidates for a "selection panel" that would in turn have recommended names to him for selection as candidates for the pool of judges. The Managing Director would then have formed his list of candidates and submitted it for approval or rejection as a whole by the IMF Board of Governors (IMF, 2002c, paragraphs 233-244 and 2003a, paragraph 13a).

The reason such a tortuous process was proposed for selecting judges was tied to how IMF proposed

\footnotetext{
${ }^{10}$ As was the practice under the bank advisory committees in the 1980 s, steering committees would probably have set up their own technical economic subcommittees to advise them.

11 In fact, sometimes IMF takes a more forceful advocacy role on behalf of the government, as was the case in actively supporting Uruguay's bond exchange offer in 2003 (IMF, 2003c, p. 204).
}

bringing the SDRM into being. As SDRM was presented as a "statutory" approach to sovereign debt restructuring, the idea was that it would become part of international law and have a number of mandatory features. The traditional way to create international law is through treaty, but IMF proposed a short cut, namely that SDRM be adopted as an amendment to the Fund's Articles of Agreement, which is a treaty to which all Fund member countries are bound, whether or not they vote for the amendment. Needing to create the SDDRM in an amendment to the Fund's Articles meant that it had to specify how to select the judges within IMF governance mechanisms. It would not have been feasible for IMF to engage or commit another international institution or body through an article of its own constitutional agreement. Were the SDRM to have been adopted by a stand-alone treaty, the process for selection of the SDDRF judges could have been designed in a more straightforward way. They could have been chosen by other credible international processes, utilizing say the United Nations or a separate governance body established under a free-standing SDRM treaty.

The question of how to design a statutory approach to sovereign debt restructuring was rendered moot by the April 2003 decision of the IMF's ministerial committee. One may only speculate whether a "statutory approach" might have succeeded had it been approached differently, with IMF perceived as less at the centre or as striving less aggressively for quick closure on the process. Given how radical the reform was and how unprepared the international community had been to consider it, it might have been more fruitful first to open a process of dialogue and consensusbuilding among relevant stakeholders, followed later by formal negotiation, leading ultimately to a standalone treaty that could have gained the support of debtor as well as creditor governments. Given that there is an international consensus on the need for clear rules on insolvency and creditors' rights in non-sovereign cases, in particular where there are cross-border issues (e.g., foreign obligations of a bankrupt firm, including taxes owed to foreign governments) and given the work that has been done on them in recent years, as in the United Nations Commission on International Trade Law (UNCITRAL) and the World Bank, it could have been agreed that global rules would also be helpful for cases of sovereign default. This is not to say that it would have been simple or quick to arrive at agreed processes, let alone that the world's governments were ready to begin the consideration in 2002 . A statutory approach 
can take time, but be worth it, as the "Law of the Sea", which took a decade to negotiate, seems to suggest.

An even bigger question is the degree to which IMF should be at the centre of any judicial-type process that might evolve in the future to better handle sovereign debt restructuring negotiations. As a public international institution, IMF should be mandated to always take independent positions in the best interest of its clients, which are ultimately the people in the borrowing countries. In practice, the Fund's shareholders have diverse interests and the client governments of IMF are its minority shareholders. In other words, it is incumbent on the majority shareholders to protect the independence of the Fund in striving for global financial stability (its original mandate) and development, a mandate it and its shareholders accepted in the Millennium Declaration (United Nations, 2000a) and the Monterrey Consensus (United Nations, 2002). Shareholders should thus avoid using IMF for domestic political or foreign policy purposes. Do they usually do this? Probably. Have they always done so? No. IMF is inescapably vulnerable to pressure from its major shareholders, who may in turn feel pressed to follow foreign policy, financial-sector or other agendas through influence over IMF. In short, a political institution is not likely to function well in a judicial role.

$\mathrm{V}$

\section{The limited contribution of collective action clauses}

Although radical reform of the debt restructuring process is no longer being actively discussed in intergovernmental forums, a number of narrower reforms are being adopted through changes in specific clauses of sovereign bond contracts. The concern is to get the cooperation of individual bondholders when it is necessary to ease the financial terms of the bonds of a country in debt crisis. Specific clauses are needed because were holders of a bond issue free to participate or not in a restructuring of a bond, then any individual bondholder would have an incentive not to participate in the expectation that the participation of the others would free up enough financial resources to fully service the remaining original bonds. As a result, too many bondholders would try to be "free riders" and the restructuring would fail.

The solution to this "collective action" problem under New York law, which accounts for about $70 \%$ of international sovereign bonds, has been to require agreement of all bondholders to change any financial terms, although other clauses could be changed with specified majorities. This makes it extremely difficult to change the financial terms, which was a solution in earlier decades when most international commercial sovereign lending was by banks. That is, bonds generally continued to be serviced even when governments defaulted on their bank loans. Today, much more international lending is in the form of bonds and a way was needed to facilitate collective action in cases of default. ${ }^{12}$ Bonds issued in London under British law or in Japan already have the basic shape of the answer, as they do not require full consensus, but instead specify super-majorities needed to change the financial terms. If the specified majority agrees, the terms of the bond are changed for all holders, so there can be no holdouts.

The question thus became what, precisely, should be the content of the new "collective action clauses" (CACs)? Two sets of model clauses have been produced, one by a working group of the Group of Ten (G-10), endorsed by its ministers and governors (Group of Ten, 2003), and the other by seven major organizations from the international financial sector

\footnotetext{
12 In fact, there is a mechanism to force a restructuring on an unwilling minority of bondholders on condition that the majority needed to change the non-financial terms of a bond agree. In this mechanism, called "exit consents", holders of a defaulted bond agree to swap it for a new issue with easier terms for the borrower and at the same time change the non-financial terms of the old bond in such a way as to make it a much inferior security (e.g., repealing the waiver of sovereign immunity, without which governments cannot be taken to court for violating the terms of the contract). The new contract clauses would make this approach unnecessary and allow the issue to be addressed more directly and openly.
} 
(EMTA and others, 2003)..$^{13}$ There was no participation by the emerging-economy governments that issue sovereign bonds in either of these exercises. However, in a sense their views are beginning to be provided, $e x$ post facto, through the precedents being established by bonds issued with CACs in 2003, as by Brazil, Mexico, South Africa and Uruguay.

The primary focus of attention has been on how big the majority should be to change the financial terms of a bond, and who should vote. The G-10 proposed that $75 \%$ of qualified bondholders be required for approval and the private-sector organizations proposed $85 \%$ approval plus no more than $10 \%$ explicitly objecting to the change. ${ }^{14}$ In the new bond issues with CACs, all but Brazil specified the $75 \%$ voting majority, with Brazil accepting $85 \%$. At this point it is not clear if the market practice will settle at $75 \%$ for the best credits and $85 \%$ for countries the market assesses as higher risk, or if $75 \%$ will become standard.

It is of course too early to tell how well these clauses will work in an actual crisis, since they are being introduced by countries that enjoy market access and are not in default. Presumably the clauses will facilitate restructuring of individual bond issues, should the need arise. Depending on how the clauses are specified, they may also facilitate "aggregation" of different bond issues (as in Uruguay's CACs) and their treatment in one larger restructuring proposal. Other clauses are expected to deter legal action by "rogue creditors" or "vulture funds" that try to recoup the face value of distressed bonds through national courts.

The clauses may thus bring bonds more firmly within the nexus of restructurable sovereign debt and establish procedures that would serve, like the Paris and London Clubs, for a debt-crisis country to organize

\footnotetext{
${ }^{13}$ The seven are the Emerging Markets Creditors Association, the Emerging Markets Traders Association (EMTA), the Institute of International Finance, the International Primary Market Association, the International Securities Market Association, the Securities Industry Association and the Bond Market Association.

${ }^{14}$ Both sets of model clauses would exclude from voting any bonds held by the issuing government or controlled by it and reject the practice of requiring voting by a quorum of participants in a bondholders' meeting, requiring instead that all bondholders be offered the chance to vote by written consent with no need for a formal meeting.
}

negotiations with this class of its creditors. While sovereign bonds have been restructured in the past, if CACs make the process more assured and clear, it will be a useful contribution. It would also be valuable to the degree that it reduced uncertainty among bond investors and increased global demand for such bonds. Most observers, however, think the latter effect will be minimal, especially as a large number of bond investors do not "buy and hold" but are constantly moving securities into and out of their portfolios (indeed, one general question is how to make emerging-market debt more attractive to long-term investors).

Yet this is not the end of the story, as even the financial-sector organizations have acknowledged that CACs address only one part of the problem in restructuring sovereign debt. This can be seen in the draft Code of Conduct for Emerging Markets that they issued as part of their package of CAC materials. The code specifies how a government should organize and deal with all its different classes of creditors in a debt crisis, as well as how the private creditors, IMF and key governments should behave. The emphasis is on taking a comprehensive, transparent and cooperative approach. This includes engaging in regular dialogue with key investors and creditors through an advisory group, disclosing details regarding all outstanding financial obligations, including proposed restructurings as well as central aspects of economic policies and programmes, including all assumptions, commitments and targets involved in any IMF-supported programme, meeting with representatives of bondholders and other key creditors and negotiating promptly, in good faith, and directly with a broadly representative group of creditors, and seeking a comparable rescheduling from all official bilateral creditors.

Private creditors are told in the draft code not to expect an IMF bail-out, to maintain trade-credit lines and roll over short-term maturities, and to negotiate in good faith. The code also urges IMF and the G-10 to support the process and it proposes that a Joint Monitoring Group drawn from debtor and creditor governments, private investors and creditors, IMF and the Bank for International Settlements should review compliance with the code. As this observer reads the code, the private financial organizations are acknowledging the essential coherence problem that the SDRM was intended to address and that remains to be addressed. 


\section{VI}

\section{Where do we go from here?}

Clearly, a lot has happened in 2002 and 2003 regarding how sovereign debt should be treated in crisis situations. A comprehensive reform proposal, the SDRM, was developed but not accepted, while changes were made in bond contracts that will alter how bond debt will be handled in future crises. Meanwhile, considerable effort has also gone into trying to specify a practical framework for assessing debt sustainability in both lowand middle-income countries, which should help inform future debt workouts, as well as assist governments in avoiding unsustainable debt situations. And yet, much remains to be done.

The private sector's draft code of conduct, as noted above, identifies the problem, but it is only a first step toward the solution, which should be a prompt, effective and fair debt workout process. The code says, in essence, that mechanisms are needed to bring all the essential stakeholders into dialogue and negotiation in order to resolve a debt crisis once it has begun, and that various measures should be taken to prevent a deteriorating situation from becoming a crisis. It suggests some steps in that direction. These should be vetted in dialogues involving the debt-issuing countries themselves, whose representatives might have proposals of their own to make about norms for their own behaviour as well as for the creditors and international institutions.

The need recognized above for a comprehensive process also leaves open the question of who coordinates it. Formally, it is the government of the country in crisis itself and informally it may be IMF, and there are drawbacks to both, as neither is a neutral party (the former as debtor and the latter as creditor). Another possibility that may be considered is coordination by an independent facilitator or mediator, who might be drawn from a pre-selected list of individuals of high character and relevant experience, identified through an international process, who agree to serve in this capacity over a certain time period. The facilitator, once activated, could be supported by a small staff of lawyers and financial economists hired for the case on hand, which could include staff of IMF and the World Bank, and be serviced through the administrative offices of the International Court of Justice or another recognized independent legal body, such as the United Nations Commission on International Trade Law.

At the United Nations, where mediation plays a large role in attempts to resolve political disputes, the Secretary-General has suggested considering it in addressing debt crises. He suggested "adding to the menu available to debtor countries a mechanism for the simultaneous, fair and full treatment of all of a country's foreign debt obligations, along with the provision of required new funds by the international community or other creditors. The use of such a mechanism, which could be invoked under specified conditions by a country already cooperating with IMF and other international financial institutions, would bring together committees representing bank creditors, bondholders, the Paris Club and other bilateral official creditors, as appropriate, plus the debtor Government" (United Nations, 2000b, paragraph 125).

A mediation service for sovereign debt negotiations has also been proposed as part of a broader Sovereign Debt Forum. As presented by Richard Gitlin ${ }^{15}$ at a "side event" of the Monterrey Conference on Financing for Development, the Forum would serve two functions: first, it would seek to enhance sovereign debt as an asset class through discussions among market professionals of the design of different lending instruments, seeking to identify best practices; and second, it would facilitate sovereign debt restructuring when requested by a debtor government, helping with early communication among the relevant parties and in organizing the parties into groups, and making available a mediator from a standing panel.

Proposals such as these that attempt to facilitate the comprehensive treatment of sovereign debt in crisis countries seem to warrant a hearing. That they have not yet had one may reflect their weaknesses, but also possibly something about the agenda for debate. The proposals discussed in this paper were supported by the G-10 and its member States, staff of IMF and the World Bank, or private financial organizations. Developing and transition economy governments, in particular, seem mainly to have reacted to proposals, rather than initiate them. Could not officials from those

\footnotetext{
${ }^{15}$ See Gitlin (2002).
} 
countries, as well as the private sector and civil society, be drawn into these debates more effectively and at an earlier stage?

In fact, there are "Southern" initiatives. For example, in June 2003 the Conference of African Ministers of Finance, Planning and Economic Development endorsed the proposal of the United Nations Economic Commission for Africa (ECA) to organize an International Conference on African Debt Relief in early 2004. The ministers believed that "we must move swiftly to meet the challenge of defining the policies, instruments and initiatives that can constitute the next step in the international community's efforts to reduce Africa's debt burden" (ECA, 2003, paragraph 28). African ministers are thus beginning to think beyond HIPC and find it more convenient to do so in a forum in Africa.

By the same token, it may also be fruitful to facilitate North-South and debtor-creditor discussions in more neutral and less consequential terrain than the forums of the Bretton Woods institutions. Involving all relevant stakeholders in a manner in which ideas might float more freely and discussion turn more innovative can only advance the dialogue.

\section{Bibliography}

Bolton, P. (2002): Towards a Statutory Approach to Sovereign Debt Restructuring: Lessons from Corporate Bankruptcy Practice around the World, Princeton, Department of Economics, Princeton University, unpublished.

ECA (Economic Commission for Africa) (2003): Ministerial Statement, Thirty-sixth Session of the Commission/Conference of African Ministers of Finance, Planning and Economic Development, Addis Ababa, 1 June [www.uneca.org].

EMTA and others (2003): Marketable bonds package, January [www.emta.org].

Fritz, T. and P. Hersel (2002): Fair and Transparent Arbitration Processes: a New Road to Resolve Debt Crises, Berlin, August [www.blue21.de].

Gitlin, R. (2002): A Proposal: Sovereign Debt Forum, Oral presentation at the International Conference on Financing for Development (Monterrey, Mexico, 18-22 March, 2002), March.

Group of Seven (2003): Finance Ministers' Statement, Deauville, France, 17 May [www.g7.utoronto.ca].

Group of Ten (2003): Report of the G-10 Working Group on Contractual Clauses [www.bis.org], March.

Herman, B. (2003): Mechanisms for dialogue and debt-crisis workout that can strengthen sovereign lending to developing countries, in A. Buira (ed.), Challenges to the World Bank and IMF: Developing Country Perspectives, London, Anthem Press.

IMF (International Monetary Fund) (2002a): Assessing Sustainability, SM/02/166, Washington, D.C., Policy Development and Review Department, 28 May.

(2002b): IMF discusses assessments of sustainability, Public Information Notice, No. 02/69, Washington, D.C., 11 July. (2002c): The Design of the Sovereign Debt Restructuring Mechanism: Further Considerations, EBS/02/201, Washington, D.C., 27 November.

(2003a): Report of the Managing Director to the IMFC on a Statutory Sovereign Debt Restructuring Mechanism, IMFC/Doc/7/03/4, Washington, D.C., 8 April.

(2003b): Debt Sustainability in Low-income Countries:

Towards a Forward-looking Strategy, Washington, D.C., Policy Development and Review Department, 23 May. (2003c): IMF Survey, Washington, D.C., 14 July.

Institute of International Finance (2003): Capital Flows to Emerging Market Economies, 15 May.

Macdonald, J. (2003): A Free Nation Deep in Debt: The Financial Roots of Democracy, New York, Farrar.

Schultz, K. and B. Weingast (2003): The democratic advantage: institutional foundations of financial power in international competition, International Organization, vol. 57, No. 1 Cambridge, Massachusetts, The MIT Press.

United Nations (2000a): Millennium Declaration, A/RES/55/2, resolution adopted by the General Assembly, New York, September.

(2000b): Report of the Secretary-General to the Preparatory Committee for the High-level Intergovernmental International Event on Financing for Development, A/AC.257/ 12, New York, 18 December.

(2002): Monterrey Consensus, Report of the International Conference on Financing for Development (Monterrey, Mexico, 18-22 March 2002), A/CONF.198/11, New York. United Nations publication, Sales No. E.02.II.A.7.

World Bank (2002): The Heavily Indebted Poor Countries (HIPC) Debt Initiative: An OED Review, Report No. 25160, Washington, D.C., 20 February, Operations Evaluation Department, 20 February. 